\title{
ADVANCES IN BIODIESEL SYNTHESIS: THE ROLE OF VARIOUS CATALYSTS
}

\author{
Nnaji, J. C. \\ Department of Chemistry, Michael Okpara University of Agriculture, Umudike, Abia State, Nigeria \\ *Phone: +2348077304555*Email: judennaji30@gmail.com
}

\begin{abstract}
Biodiesel is a renewable, clean-burning, and biodegradable fuel which can be synthesized from readily available domestic and natural sources, such as edible, non-edible and waste cooking oils, which may serve as a substitute to petro-diesel. It is produced by catalytic transesterification of fats and oils. A number of researches has been devoted to discovering a benign catalyst, especially heterogeneous acid catalyst that could convert non-edible and waste cooking oils with high free fatty acid into biodiesel, in an attempt to reduce the cost of production. The cost of production of biodiesel is still far higher than that of conventional petro-diesel, owing to the cost of edible oil currently being used, processes involved, and cost of conventional heterogeneous catalysts employed. This study assessed the role of various catalysts; homogeneous, heterogenous and enzyme-catalyzed transesterification reactions, in terms of their advantages and disadvantages in biodiesel production in order to establish very promising catalysts. Some methods of heterogeneous acid catalysts were also highlighted. Amongst the common heterogeneous catalyst, carbon-based solid acid catalysts were recommended as very promising solid acid catalyst that can utilize the non-edible oils in biodiesel production. The advantages of carbon-based solid acid catalysts include cheap readily available raw materials for their synthesis, easier production processes, relative stability, high reusability and potential for utilizing waste and nonedible oils for biodiesel production.
\end{abstract}

Keywords: biodiesel, catalysts, oil, petro-diesel, reusability, roles, synthesis

LICENSE: This work by Open Journals Nigeria is licensed and published under the Creative Commons Attribution License 4.0 International License, which permits unrestricted use, distribution, and reproduction in any medium, provided this article is duly cited.

COPYRIGHT: The Author(s) completely retain the copyright of this published article.

OPEN ACCESS: The Author(s) approves that this article remains permanently online in the open access (OA) mode.

QA: This Article is published in line with "COPE (Committee on Publication Ethics) and PIE (Publication Integrity \& Ethics)". 


\section{INTRODUCTION}

The finite nature of petroleum-derived fuels, global energy crisis and climate change, have necessitated the search for green bio-fuels that are renewable, eco-friendly and can serve as substitute to petro-derived fuels. In this regard, bio-ethanol and biodiesel are believed to have great potential and a promising future, especially for the transportation sector. As a result, research interest is being focused on this area. Biodiesel is regarded as the best substitute for conventional petro-based diesel fuel (Endalew et al., 2011; Ishola, 2013). It is a fatty acid methyl ester derived from vegetable oils and animal fats by transesterification reaction with primary alcohols, mainly methanol (Kouz et al., 2007; Babajide et al., 2015). According to European Parliament, in 2003/30/EC Directive, biodiesel is defined as methyl-ester produced from vegetable or animal oils of diesel quality to be used as bio-fuel (MacLeod et al., 2008). It is recognized as a notable alternative to the widely used petroleum-derived diesel because they share similar characteristics such as good cetane number and combustion efficiency, even though biodiesel has a lower heating value. There are some notable advantages of biodiesel over petro-diesel. It is renewable, clean-burning, readily available, biodegradable and can be generated from domestic and natural sources such as edible oils; soybean, rapeseed, palm, coconut, etc; non-edible oil sources such as algae, jatropha, neem; and waste cooking oils (used oils) (Akande and Olorunfemi, 2009; Mustafa and Havva, 2010; Elegbede and Guerrero, 2016; Ogbonna et al., 2015). Biodiesel is manufactured by transesterification reaction using various homogenous, heterogenous and enzyme-catalysts. The homogeneous catalysts, widely used in commercial processes, have some disadvantages; (1) they cannot be reused, (2) they produce large amounts of waste water, and (3) they produce low grade glycerol as byproduct.

In contrast, the heterogeneous catalytic process, offering simplified production and purification processes, is expected to be an effective low-cost with minimal environmental-impact biodiesel production process. In fact, several researchers have reported the potential economic advantages of the heterogeneous catalytic process over the alternative homogeneous process (West et al., 2008; Marchetti and Errazu, 2008; Sakai et al., 2009). For example, the heterogeneous catalysts incur 4-20\% lower refining costs than the homogeneous catalysts (Marchetti and Errazu, 2008). In this regard, many heterogeneous base and acid catalysts suitable for synthesis of biodiesel from various oils have been developed and evaluated in biodiesel production processes. Furthermore, a review comparing inorganic solid catalysts has already been published (Zabeti et al., 2009). However, heterogeneous solid base catalysts have their setbacks. Just like the homogeneous base catalysts, they are sensitive to Free Fatty Acid (FFA) content in the oil due to their basicity property, poisoning when exposed to ambient air, soap formation if the FFA content in the oil is more than $2 \%$ by weight, reduced biodiesel yield and leaching of their active sites which may result in product contamination (Kouz et al., 2007; Guan et al., 2009; Chin et al., 2009).

Two major factors have been identified that contribute to the cost of production of biodiesel; the cost of raw material (feedstock) and the cost of processing. The cost of refined vegetable oil feedstock is significantly high. On the contrary, waste cooking oil (WCO) and non-edible oils are twice or thrice cheaper than the cost of the refined vegetable oil owing to their high FFA (Mustafa and Havva, 2010; Adepoju and Olawale, 2014). Experience has shown that the cost of production of biodiesel is greatly reduced with the application of heterogeneous acid catalysts in industries. This is because heterogeneous acid catalysts are tolerant to high FFA and water content such that additional product separation costs associated with homogeneous catalysts are eliminated (Endalew et al., 2011). In order to produce biodiesel that is cheaper than petro-diesel, heterogeneous catalysts that are very 
cheap, available, operates at mild temperatures and pressures, with longer durability, non-corrosive, recyclable, environmentally benign and tailorable with higher selectivity makes for easy separation of products, should be vigorously pursued. Such catalyst should also have a very large surface area and pore-volume with very high tolerance to feedstock of high FFA since such feedstock is cheaper than refined oils.

Currently, biodiesel research is focused on exploring new and sustainable enzyme and solid acid catalysts for transesterification reaction with cheap non-edible oils. Solid acid catalysts and biocatalyst are used but solid acid catalysts tend to enjoy more research interest than biocatalysts in this regard because they are more stable. In addition, it is believed that solid acid catalysts have a strong potential to replace liquid acid catalyst (Jacobson et al., 2008). They are insensitive to high FFA content and esterification and transesterification occurs simultaneously (Kulkarni et al., 2006), eliminating the washing step of biodiesel (Jitputti et al., 2006), easy separation of the catalyst from the reaction medium, resulting in lower product contamination level, easy regeneration and recycling of catalyst and reduce corrosion problem, even with the presence of acid species (Suarez et al., 2007). High cost of solid catalysts, replacement of edible oil with non-edible oil with high FFA and limited mass transfer rate coupled with glycerol by-produced with biodiesel during transesterification reaction may have remained a very big challenge to researchers of heterogeneous catalysts. An ideal heterogeneous catalyst, either solid base or solid acid for transesterification reaction should have characteristics such as an interconnected network of large pores; a moderate to high concentration of strong acid or base sites; a hydrophobic surface (Kulkarni et al., 2006); economical in operation with thermal and chemical stability. This review explores the potentials of developing cheap and environmentally benign carbon-based heterogeneous acid catalysts from agro-wastes which can efficiently handle feed stocks with high FFA.

\section{FEEDSTOCKS FOR BIODIESEL PRODUCTION}

The concept of using vegetable oil as a transportation fuel dates back to 1893 when Dr. Rudolf Diesel developed the first diesel engine to run on vegetable oil. Vegetable oils have become more attractive recently because of its environmental benefits and the fact that it is made from renewable resources. Vegetable oils have the potential to substitute a fraction of petroleum distillates and petroleum-based petrochemicals in the near future (Mustafa and Havva, 2010). The basic constituent of vegetable oils is triglyceride (90 to 98\%) and small amounts of mono- and diglycerides (Ababe et al., 2011). Normally, triglycerides of vegetable oils and animals' fats consist of several different fatty acids which have different physical and chemical properties and the composition of these fatty acids are the most important parameters influencing the corresponding properties of vegetable oils and animal fats (Knothe and Krahl, 2004). Vegetable oils can be classified as edible and non-edible. Edible oils for biodiesel include oils from rapeseed, soybean, canola, sunflower, peanut, palm oil (Alamu et al., 2007; Aransiola et al., 2012; Aransiola et al., 2014) and non-edible vegetable oils include Jatropha curcas, sea mango, polanga, pongamia, etc. Feedstock which compete with food crops have been put in question for their sustainability as the world food prices show an upsurge. Research focused on feedstocks that do not compete with food crops is currently on constant increase (Pinzi et al., 2009). Non-edible oils have been approved for their potential for production of sustainable biodiesel and ecological benefit. For example, Jatropha curcas is a multipurpose, drought resistant, oil seed bearing plant originating from South America and now grows in many areas of the tropics and subtropics like Nigeria. Seed of jatropha curcas plant has a high oil content which can be used for biodiesel production. 
Direct use of vegetable oils and animal fats as combustible fuel is not suitable due to their high kinematic viscosity and low volatility. Furthermore, its long-term use posed serious problems such as deposition, ring sticking and injector chocking in engine (Muniyappa et al., 1996). Therefore, vegetable oils and animal fats must be subjected to chemical reaction such as transesterification to reduce the viscosity of these oils. In this reaction, triglycerides are converted into fatty acid methyl ester (FAME), in the presence of short chain alcohol, such as methanol or ethanol, and a catalyst, such as alkali or acid, with glycerol as a by-product (Oniya and Bamgboye, 2014). The type of feedstock and alcohol used in the reaction affects the quality and the cost of production. Higher chain alcohols result in higher viscosity and increased production cost. Methanol and ethanol are the most frequently used alcohols in the transesterification reaction. Methanol obtained from biomass is preferred because it is compatible with an eco-friendly reactant for producing biodiesel. The presence of high FFA and impurities in non-edible vegetable oils and waste cooking oil require a special attention in the design and selection of catalysts. For high FFA containing oils, pre-treatment by esterification reaction is required to avoid the complex problem of FFA during and post transesterification reaction (Endalew et al., 2011).

\section{CATALYSIS IN TRANSESTERIFICATION OF VEGETABLE OIL}

Transesterification reaction can proceed with catalytic and non-catalytic mechanisms. The non-catalytic mechanism occurs at supercritical conditions. Supercritical methods require higher temperature and pressure which increase the parasitic energy required for the process and this translates into higher production cost. For this reason, catalytic methods of biodiesel production at low temperature and pressure are the most commonly preferred transesterification methods (Demirbas, 2005). Transesterification reactions can be catalyzed by alkalis (Anwar et al., 2010;), acids (Li et al., 2010) or enzymes [Dizge and Keskinler., 2008). The catalytic transesterification of vegetable oils with methanol is an important industrial method used in biodiesel synthesis. Also known as methanolysis, this reaction is well studied and established using acids or alkalis, such as sulphuric acid or sodium hydroxide as catalysts. However, these catalytic systems are less active or completely inactive for long chain alcohols. Usually, industries use sodium or potassium hydroxide or sodium or potassium methoxide as catalyst, since they are relatively cheap and quite active for this reaction (Macedo et al., 2006). Enzymes-catalyzed procedures, using lipase as catalyst, do not produce side reactions, but lipases are very expensive for industrial scale production and a three-step process is required to achieve a 95\% conversion (Stavarache et al., 2005).

\section{HOMOGENEOUS ALKALI CATALYZED TRANSESTERIFICATION METHOD}

Currently, biodiesel is commonly produced using homogeneous base catalyst, such as sodium hydroxide $(\mathrm{NaOH})$ or potassium hydroxide $(\mathrm{KOH})$. These catalysts are commonly used in industry for several reasons: (1) ability to catalyze reaction at low reaction temperature and atmospheric pressure, (2) high conversion can be achieved in a minimal time, (3) widely available and economical (Lotero et al., 2005). In fact, it was reported that the rate for base-catalyzed reaction could be 4000 times faster compared to acidic catalyzed (Fukuda et al., 2001, Kulkarni et al., 2006). However, the use of this catalyst is limited only for refined edible vegetable oils with less than 0.5 wt.\% FFA (Wang et al., 2006) or acid value less than $1 \mathrm{mg} \mathrm{KOH/g} \mathrm{(Felizardo} \mathrm{et} \mathrm{al.,} \mathrm{2006).} \mathrm{Nevertheless,} \mathrm{it} \mathrm{is}$ clear that the FFA content in oil feedstock should be as low as possible (ranging from less than 0.5 wt.\% to less than 2 wt.\%) for base-catalyzed transesterification reaction. For example, if a waste cooking oil has an average FFA content more than $6 \mathrm{wt}$ \%, base catalyst would definitely not be suitable (Lotero et al., 2005). FFA consists 
of long carbon chain that is disconnected from glycerol backbone. If an oil or fat containing high FFA such as oleic acid is used to produce biodiesel, an alkali catalyst will typically react with the FFA to form soap, which is highly undesirable (Kulkarni et al., 2006). This reaction is highly undesirable since it will deactivate the catalyst from accelerating the transesterification reaction. Furthermore, excessive soap in the product can drastically reduce the fatty acid methyl ester (FAME) yield and inhibit the subsequent purification process of biodiesel, including glycerol separation and water washing (Nag, 2008). Besides, high water content in waste cooking oil also affects the methyl ester yield. When water is present, particularly at high temperatures, it can hydrolyze triglycerides to diglycerides and form free fatty acid.

\section{HOMOGENEOUS ACID CATALYZED TRANSESTERIFICATION METHOD}

Since liquid base-catalyzed transesterification process poses a lot of problems especially for oil or fat with high FFAs concentration, liquid acid catalysts are proposed in order to overcome the limitations. To date, the most investigated catalysts for acid-catalyzed system are sulphuric acid $\left(\mathrm{H}_{2} \mathrm{SO}_{4}\right)$ and hydrochloric acid $(\mathrm{HCl})$. Acid catalyzed transesterification holds an important advantage with respect to base-catalyzed process: acid catalyst is insensitive to the presence of FFAs in the feedstock (Kulkarni et al., 2006) and can catalyze esterification and transesterification simultaneously (Jacobson et al., 2008). Esterification is a chemical reaction in which two reactants, typically an alcohol (e.g. methanol) and an acid (e.g. FFA) react to form an ester as the reaction product. It was reported that acid catalysis is more efficient when the amount of FFA in the oil exceeds 1 wt.\% (Zhang et al., 2003). In addition, economic analysis has proven that acid catalyzed procedure, being a one-step process, is more economical than the base-catalyzed process which requires an extra step to convert FFA to methyl esters (Zhang et al., 2003). However, acid-catalyzed system is not a popular choice for commercial applications due to slower reaction rate, requirement of high reaction temperature, high molar ratio of alcohol to oil, separation of the catalyst, serious environmental and corrosion related problems (Jacobson et al., 2008). In a study of acid-catalyzed transesterification of waste cooking oil using $\mathrm{H}_{2} \mathrm{SO}_{4}$, Wang et al. (2006) reported that the yield of FAME increased with increased reaction time, higher methanol to oil ratio and higher catalyst loading. The conversion of waste cooking oil was more than $90 \%$ at a reaction time of $10 \mathrm{~h}$ with ratio of methanol to oil at 20:1 and 4 wt. $\% \mathrm{H}_{2} \mathrm{SO}_{4}$ (referencing weight of oil). These data indicate that acid-catalyzed transesterification process requires more severe reaction conditions (such as increased reaction time) than base-catalyzed reaction.

\section{TWO-STEP HOMOGENEOUS BASE AND ACID CATALYZED TRANSESTERIFICATION METHOD}

Since homogeneous acid and base catalysts have their own advantages and limitations, some studies have attempted to use a combination of both catalysts to synthesize biodiesel from oil containing high FFAs. Initially, acid catalyst was employed to convert FFAs to ester through esterification. When the FFAs content in the oil drops to less than $0.5-1 \mathrm{wt} . \%$, transesterification of the oil can then be performed by using a base catalyst. A pilot plant has been developed to produce biodiesel from feedstock with high FFAs content via two steps method; esterification and transesterification (Canakci and VanGerpen, 2003). The feedstock was first treated with $\mathrm{H}_{2} \mathrm{SO}_{4}$ to reduce the level of FFAs to below $1 \mathrm{wt} . \%$, followed by transesterification process catalyzed by homogeneous base, $\mathrm{KOH}$. Although high FAME yield was achievable, the rate of FFA esterification reaction was relatively very slow. Thus, higher amount of acid catalyst is required to accelerate the rate of reaction. The drawback of this twostep process is even more pronounced due to the requirement of extra separation steps to remove the catalyst in 
both stages. Although the problem of catalyst removal from the first stage can be avoided by using base catalyst from the second stage through neutralization process, the use of extra base catalyst will add to the cost of biodiesel production (Kulkarni et al., 2006).

\section{HETEROGENEUOUS CATALYZED TRANSESTERIFICATION METHOD}

Commercial production of biodiesel is based on homogeneous catalysts and the cost of biodiesel production is about 1.5 to 3 times more expensive than petroleum-based diesel (Di Serio et al., 2008). Two main factors that contribute to the cost of production are the cost of feedstock and the cost of processing. The cost of feedstock in the form of virgin vegetable oils is significantly higher, approximately 70 to $95 \%$ of the total cost of the biodiesel production but the use of non-edible and waste cooking oils can lower the feedstock cost by twice or thrice the amount (Haas et al., 2006; Dorodoa et al., 2006). Experiences obtained from different industrial processes show that heterogeneous catalysts have proved to be cost effective and render convenient production process as an ecofriendly method (Tanabe and HoE'Iderich, 1999). The use of heterogeneous catalysts for biodiesel production from different feedstock has been studied by many researchers (Lee et al., 2009; Canakci and Sanli, 2008). Several findings showed promising results for performance of heterogeneous catalysts in biodiesel production compared with homogenous catalysts. Heterogeneous catalysts are relatively tolerant to high FFA and water content. Development of efficient and low-cost heterogeneous catalysts for transesterification of low-cost vegetable oils can lead to a much lower total production cost of biodiesel. Heterogeneous catalysts can be grouped as basic, acidic or biological (enzymatic) types. Selection of a catalyst from these groups depends on the type of feedstock, operating conditions, required catalyst activity, cost and availability (Helwani et al., 2009). Solid acids favour both esterification and transesterification reactions simultaneously for biodiesel production from non-edible oils with high FFA. Inorganic heterogeneous catalysts are mainly used because they are cheap and available, stable at high temperatures and pressures, have longer durability, tailorable into the desired morphology and are easy to regenerate. The shortcomings of these catalysts are the necessity for harsh reaction (temperature and pressure) conditions such as high temperatures for the preparation and modification of the active phases.

Commercialization of inorganic heterogeneous catalyst for biodiesel production is still in the infant stage. In 2006, a 160,000 tone/year commercial biodiesel plant started-up using a heterogeneous catalysis developed by Axens, Institute Franc, ais du Petrole (IFP) (Di Serio et al., 2008). The plant has two continuous fixed bed reactors with zinc and aluminium oxide catalysts and use various type of vegetable oils. This plant technology is now spreading to different parts of the world such as US, Sweden, Malaysia (Axen, 2010). The development of new and cost-effective heterogeneous catalyst can further promote the commercialization of biodiesel production from different resources for direct onsite production and consumption (Ababe et al., 2011). The need for high temperature and pressure reaction conditions for these types of catalysts increases the overall energy input for a biodiesel production process.

\section{HETEROGENEOUS BASE-CATALYZED TRANSESTERIFICATION METHOD}

Many solid base catalysts have been developed for biodiesel production, such as basic zeolites, alkaline earth metal oxides and hydrotalcites. Moreover, alkaline earth metal oxides especially calcium oxide, $\mathrm{CaO}$ have attracted much attention due to their relatively high basic strength, low solubility in methanol and can be synthesized from cheap sources like limestone and calcium hydroxide (Zabeti et al., 2009). Kouzu et al. (2008) 
reported that $\mathrm{CaO}$ obtained from calcinations of pulverized limestone, $\mathrm{CaCO} 3$ at $900{ }^{\circ} \mathrm{C}$ for $1.5 \mathrm{~h}$ in the flow of helium gas exhibited substantial result in transesterification of refined soybean oil. The yield of FAME was $93 \%$ after $1 \mathrm{~h}$ reaction time at methanol reflux temperature and methanol to oil ratio 12:1.

However, the yield of FAME dropped to $66 \%$ when waste cooking oil with FFA content 2.6 wt.\% was used under the same reaction condition. It is obvious that the basic sites of $\mathrm{CaO}$ were poisoned by strong adsorption of FFAs on the surface of the catalyst (Kouzu et al., 2008). Consequently, a portion of the catalyst changed into calcium soap by reacting with the FFAs adsorbed, resulting in low recovery of catalyst. The concentration of $\mathrm{Ca}$ in the reaction product was $3065 \mathrm{ppm}$ which exceeded the basic standard of biodiesel, the concentration of mineral matter should be below 200 ppm. In addition, some researchers also pointed out that soluble substance from $\mathrm{CaO}$ can leached out during transesterification. Gryglewicz (1999) stated in his paper that calcium oxide slightly dissolves in methanol while transesterification of sunflower oil was conducted with methanol in which a slight amount of calcium oxide was found to dissolve in the reaction product (Granados $e t$ al., 2007). Kouzu et al. (2008) further identified the soluble substance as calcium diglyceroxide in which $\mathrm{CaO}$ reacted with glycerol during transesterification of soybean oil with methanol. Thus, an extra purification step is needed such as ion-exchange resin to remove the soluble content in the biodiesel. Apart from that, Granados et al. (2007) used activated $\mathrm{CaO}$ as a solid base catalyst in the transesterification of sunflower oil to investigate the role of water and carbon dioxide on the deterioration of the catalytic performance upon contact with air for different period of time. The study showed that $\mathrm{CaO}$ was rapidly hydrated and carbonated in the air. No calcium oxide peak was detected in the samples after exposed to air for more than 20 days. It was further reported that the active sites of $\mathrm{CaO}$ were poisoned due to chemisorption of carbon dioxide and water on the surface sites to form carbonates and hydroxyl groups, respectively. However, the catalytic activity of $\mathrm{CaO}$ can be regenerated if $\mathrm{CaO}$ is subjected to an activation treatment at $700{ }^{\circ} \mathrm{C}$ in order to remove the main poisoning species (the carbonate groups) from the surface.

However, leaching of the catalyst was still observed in the transesterification reaction although prior thermal treatment was employed. Besides, magnesium oxide $(\mathrm{MgO})$ which is produced by direct heating of magnesium carbonate or magnesium hydroxide was also investigated on its catalytic activity in transesterification. Di Serio et al. (2006) reported that $\mathrm{MgO}$ was efficient in transesterification of soybean oil, however high reaction temperature $\left(180^{\circ} \mathrm{C}\right)$ is required. At low reaction temperature $\left(100^{\circ} \mathrm{C}\right), \mathrm{MgO}$ catalyst exhibited very low catalytic performance since the FAME yield observed was less than $20 \%$. This result was in agreement with Cantrell et al. (2005) and Gryglewicz (1999), as they reported low or even no activity when using $\mathrm{MgO}$ in transesterification reactions performed at $60{ }^{\circ} \mathrm{C}$. In fact, $\mathrm{MgO}$ has the weakest basic strength among group II oxides, such as, $\mathrm{CaO}$ and strontium oxide ( $\mathrm{SrO}$ ) (Kouzu et al., 2008). Nevertheless, mixed magnesium-alumina ( $\mathrm{Mg}-\mathrm{Al})$ oxide prepared by using hydrotalcites $\left(\mathrm{Mg}_{6} \mathrm{Al}_{2}(\mathrm{OH})_{16} \mathrm{CO}_{34} \mathrm{H}_{2} \mathrm{O}\right)$ as precursor and calcined at high temperature has manifested the basic sites of the catalyst (Xie et al., 2006). More than $90 \%$ of FAME yield was observed when using $\mathrm{Mg}-\mathrm{Al}$ oxide as catalyst though high reaction temperature was required (Di Serio et al., 2006). Moreover, high concentration of $\mathrm{Mg}$ and $\mathrm{Al}$ ions were found to leach out from the catalyst, resulting in the requirement of extra purification step (Oku et al., 2006). 


\section{HETEROGENEOUS ACID-CATALYZED TRANSESTERIFICATION METHOD}

Biodiesel research is currently focused on exploring new and sustainable solid acid catalysts for transesterification reaction. In addition, it is believed that solid acid catalysts have a strong potential to replace liquid acid catalyst (Jacobson et al., 2008). The advantages of using solid acid catalyst are (1) they are insensitive to FFA content, (2) esterification and transesterification occurs simultaneously (Kulkarni et al., 2006), (3) eliminating the washing step of biodiesel (Jitputti et al., 2006), (4) easy separation of the catalyst from the reaction medium, resulting in lower product contamination level, (5) easy regeneration and recycling of catalyst and (6) reduced corrosion problem, even with the presence of acid species (Suarez et al., 2007). In fact, the development of heterogeneous catalyst system holds an important factor for incorporation into a continuous flow reactor (Lotero et al., 2005). Such continuous process can minimize product separation and purification costs, making it economically viable and able to compete with commercial petroleum-based diesel fuel (de Almeida et al., 2008). The ideal solid acid catalyst for transesterification reaction should have characteristics such as an interconnected network of large pores, a moderate to high concentration of strong acid sites, and a hydrophobic surface (Kulkarni et al., 2006). However, research on direct use of solid acid catalyst for biodiesel production has not been widely explored due to its limitation in slow reaction rate and possible undesirable side reactions. Some of the solid acid catalysts that have been reported so far for biodiesel production are sulfonated zirconium oxide $\left(\mathrm{ZrO}_{2}\right)$, titanium oxide $\left(\mathrm{TiO}_{2}\right)$, Tin oxide $\left(\mathrm{SnO}_{2}\right)$, zeolites, sulfonated ion exchange resins, sulfonated mesostructured silica, sulphonated carbonbased catalyst and heteropolyacids (HPAs).

\section{SULPHONATED ZIRCONIUM OXIDE CATALYST}

There have been several studies on the usage of zirconium oxide $\left(\mathrm{ZrO}_{2}\right)$ as a solid acid catalyst for transesterification of different feedstock due to its strong surface acidity. The acidity property can even be enhanced by coating the surface of this metal oxide with anions like sulphate and tungstate. This can be done by impregnating $\mathrm{ZrO}_{2}$ with acidic solution such as sulphuric acid $\left(\mathrm{H}_{2} \mathrm{SO}_{4}\right)$ to become sulphated zirconia, $\mathrm{SO}_{4}{ }^{2-} / \mathrm{ZrO}_{2}$ (Miao and Gao, 1997). Jitputti et al. (2006) reported that $\mathrm{SO}_{4}{ }^{2-} / \mathrm{ZrO}_{2}$ can give promising results in transesterification of palm kernel oil and crude coconut oil with methyl ester yield reaching as high as $90.3 \%$ and $86.3 \%$, respectively.

However, when unsulphated $\mathrm{ZrO}_{2}$ was used as catalyst instead of $\mathrm{SO}_{4}{ }^{2-} / \mathrm{ZrO}_{2}$, only $64.5 \%$ (palm kernel oil) and $49.3 \%$ (crude coconut oil) of methyl ester yield were attained, respectively. This eventually indicates that modification of metal oxide surface acidity is the key factor in obtaining high conversion of triglycerides. Application of $\mathrm{ZrO}_{2}$ in esterification of waste cooking oil was also reported by Park et al. (2008). In their study, tungsten oxide $\mathrm{WO}_{3}$ was incorporated into $\mathrm{ZrO}_{2}$ rather than impregnating with $\mathrm{H}_{2} \mathrm{SO}_{4}$. It was found that $\mathrm{WO}_{3} / \mathrm{ZrO}_{2}$ has higher stability than $\mathrm{SO}_{4}{ }^{2-} / \mathrm{ZrO}_{2}$, and therefore avoiding the leaching of acid sites into the reaction media. Even if $\mathrm{WO}_{3}$ leached into the reaction media, it does not contaminate the product (Park et al., 2008, Park et al., 2010).

From the study, it was found that $85 \%$ of FFA conversion was attained in a packed-bed reactor after 20 $\mathrm{h}$ of reaction time at $75{ }^{\circ} \mathrm{C}$, but decreased to $65 \%$ and remained stable thereafter. The reason given was due to the oxidation of $\mathrm{WO}_{3}$ after long term exposure to FFA (a reducing agent) that resulted to a decrease in catalytic activity. Therefore, leaching of $\mathrm{WO}_{3}$ was ruled out as the main reason for catalyst deactivation. In addition, $\mathrm{WO}_{3} / \mathrm{ZrO}_{2}$ could be simply regenerated by air re-calcination. However, further study on catalyst and process 
optimization and also the oxidation state of $\mathrm{WO}_{3}$ are still required. Despite the high acidity of $\mathrm{SO}_{4}{ }^{2-} / \mathrm{ZrO}_{2}$, however it is known to suffer significant deactivation during liquid-phase transesterification, possibly due to sulphate leaching (Omota et al., 2003). Catalyst leaching was tested by dissolving fresh $\mathrm{SO}_{4}{ }^{2-} / \mathrm{ZrO}_{2}$ catalyst with water. The $\mathrm{pH}$ of the suspension was found to decrease quickly as a result of the hydrolysis of the sulphate groups to $\mathrm{H}_{2} \mathrm{SO}_{4}$ and $\mathrm{HSO}_{4}{ }^{-}$. This will cause the transesterification to occur via homogeneous acid catalysis and therefore interfere with the measurements of heterogeneous catalytic activity. Besides leaching of $\mathrm{SO}_{4}{ }^{2-} / \mathrm{ZrO}_{2}$, the preparation process and $\mathrm{ZrO}_{2}$ are very expensive.

Recently, a new preparation method was proposed which involved using chlorosulfonic acid, $\mathrm{HSO}_{3} \mathrm{Cl}$ instead of the conventional impregnation of $\mathrm{H}_{2} \mathrm{SO}_{4}$ (Yadav and Murkute, 2004). The prepared $\mathrm{SO}_{4}{ }^{2-} / \mathrm{ZrO}_{2}$ exhibited higher catalytic activity in transesterification and no sulfate leaching was observed. However, $\mathrm{HSO}{ }_{3} \mathrm{Cl}$ is a very hazardous chemical, a slight exposure for a very short period of time may cause death or fatal injury (Kapias and Griffiths, 2001).

\section{SULPHONATED TITANIUM OXIDE CATALYST}

Titanium dioxide $\left(\mathrm{TiO}_{2}\right)$ is among transition metal oxides that have attracted attention for biodiesel production due to their acidic properties. In addition, introduction of sulphuric group on the surface of $\mathrm{TiO}_{2}$ will enhance the acid strength of the catalyst. However, there are still very limited studies reported in the literature describing the application of such catalyst for transesterification of vegetable oils (de Almeida et al., 2008). Chen et al. (2007) had evaluated the catalytic activity of $\mathrm{SO}_{4}{ }^{2-} / \mathrm{TiO}_{2}$ and $\mathrm{SO}_{4}{ }^{2-} / \mathrm{ZrO}_{2}$ for transesterification of cotton seed oil high in FFAs content to FAME. It was interestingly observed that the activity of this catalyst is proportional to its specific surface area. $\mathrm{SO}_{4}{ }^{2-} / \mathrm{TiO}_{2}$ with a specific surface area of $99.5 \mathrm{~m}^{2} / \mathrm{g}$ can achieved a higher yield of $90 \%$ compared to $\mathrm{SO}_{4}{ }^{2-} / \mathrm{ZrO}_{2}$ with a specific surface area of $91.5 \mathrm{~m}^{2} / \mathrm{g}$, which only achieved a yield of $85 \%$.

However, this catalyst requires high reaction temperature $\left(230{ }^{\circ} \mathrm{C}\right)$, a negative factor for industrial application. When lower reaction temperature $\left(120^{\circ} \mathrm{C}\right)$ and reaction time $(1 \mathrm{~h})$ were used, the FAME yield obtained was only $40 \%$ (de Almeida et al., 2008). It was proposed that the reactivity of $\mathrm{SO}_{4}{ }^{2-} / \mathrm{TiO}_{2}$ can be increased by introducing a secondary metal, $\mathrm{SiO}_{2}$ to produce $\mathrm{SO}_{4}{ }^{2-} / \mathrm{TiO}_{2}-\mathrm{SiO}_{2}$ (Peng et al., 2008). By adding $\mathrm{SiO}_{2}$ to $\mathrm{SO}_{4}{ }^{2-} / \mathrm{TiO}_{2}$, the specific surface area of the catalyst increased to $258 \mathrm{~m}^{2} / \mathrm{g}$ with an average pore diameter of $10.8 \mathrm{~nm}$. The synthesized $\mathrm{SO}_{4}{ }^{2-} / \mathrm{TiO}_{2}-\mathrm{SiO}_{2}$ was then subjected to transesterification of refined cotton seed oil blended with 50\% oleic acid. The optimum FAME yield obtained was more than $90 \%$ at reaction temperature 200 ${ }^{\circ} \mathrm{C}$, methanol to oil ratio 9:1, catalyst loading $3 \mathrm{wt} . \%$ and a shorter reaction time of $3 \mathrm{~h}$. However, the reaction temperature was considered very high when compared to homogeneous catalyst which lies between 60 and 100 ${ }^{\circ} \mathrm{C}$. However, more in-depth research especially on the leaching characteristic of this catalyst must be carried out to justify its potential for industrial biodiesel production (Man et al., 2010).

\section{ZEOLITES}

Zeolites are microporous crystalline solids which contain silicon ( $\mathrm{Si}$ ), aluminium $(\mathrm{Al})$ and oxygen in their framework. One of the common applications of zeolite (inorganic solid catalyst) is for the production of organic compounds such as ester (Balaji and Chanda, 1998). This is because the characteristic of zeolite can be tailored to suit its function. For instance, zeolite can be synthesized with different crystal structures, pore sizes, $\mathrm{Si} / \mathrm{Al}$ ratios and proton exchange levels (Lotero et al., 2005). Therefore, the acid strength of the catalyst can be controlled by 
changing the aluminosilicate framework such that it fits specific reaction requirements (Corma and Garcia, 1997). However, it should be noted that low surface acidity may cause slow reaction rate whereas extremely high acidity may cause deactivation due to coking or possible formation of undesirable by-products. Moreover, zeolite also has another key feature. Since zeolite with specific pore structure and surface hydrophobicity can be tailored according to substrate's size and polarity (Lotero et al., 2005), therefore only molecules with appropriate dimension are allowed to enter the zeolite cavity and diffusing through the pores (Xavier et al., 2009). Although zeolite has numerous advantages over other heterogeneous catalysts, however its catalytic activity in transesterification reactions is relatively low. This is mainly due to diffusion limitation of bulky reactants (triglycerides) into the microporous structure of zeolite (Kiss et al., 2006). Triglycerides with an average molecular size of $2 \mathrm{~nm}$ suffered mass transfer resistance in the zeolite's micropore (1-2 nm). Therefore, it is believed that transesterification reaction only occurs on the external surface of zeolite crystal. In order to overcome this limitation, the pore size and structure of zeolite must be adjusted by varying the $\mathrm{Si} / \mathrm{Al}$ ratio.

Generally, higher Si/Al ratio resulted in zeolite with larger-pore size (Okuhara, 2002) but with weaker acidic strength (Chung et al., 2008). Thus, although zeolite with larger-pore size may overcome the diffusion limitation problem but the reaction rate is still rather slow due to low acidity strength. Brito et al., (2007) reported the application of different zeolite Y catalysts in transesterification of waste cooking oil. Several types of zeolite $\mathrm{Y}$ with different concentration of $\mathrm{Al}_{2} \mathrm{O}_{3}$ and $\mathrm{Na}_{2} \mathrm{O}$ were utilized in the reaction, however, the catalysts were found to give poor performance. The highest biodiesel yield attained was only $26.6 \%$ although the reaction was carried out at high reaction temperature of $460{ }^{\circ} \mathrm{C}$, methanol to oil molar ratio of 6 and reaction time of $22 \mathrm{~min}$. Similar reports on the low activity of zeolite catalyst when used in transesterification were also reported in recent publications (Kiss et al., 2006, Okuhara, 2002).

\section{HETEROPOLYACIDS (HPAS)}

Heteropolyacids (HPAs) catalysts have attracted researcher's attention recently due to their excellent water tolerant ability, possession of strong Brønsted acidity (stronger than conventional homogeneous acid, $\mathrm{H}_{2} \mathrm{SO}_{4}$ ) and high catalytic activity and stability (Sivasamy et al., 2009, Narasimharao et al., 2007). Typical HPAs which are easily available are $\mathrm{H}_{3} \mathrm{PW}_{12} \mathrm{O}_{40}, \mathrm{H}_{4} \mathrm{SiW}_{12} \mathrm{O}_{40}, \mathrm{H}_{3} \mathrm{PMo}_{12} \mathrm{O}_{40}$ and $\mathrm{H}_{4} \mathrm{SiMo}_{12} \mathrm{O}_{40}$ (Zhang et al., 2010). In addition, adding appropriate ratio of salt $\left(\mathrm{Cs}^{+}, \mathrm{NH}_{4}^{+}\right.$and $\left.\mathrm{Ag}^{+}\right)$to HPAs will dramatically increase its surface area and allow easier accessibility of reactant to its active sites (Narasimharao et al., 2007). However, it should be noted that HPAs can be slightly soluble in the reaction media and resulting to homogeneous reaction, which contributed to the overall reaction rate (Sivasamy et al., 2009). Therefore, leaching of active sites may also easily occur and cause serious catalyst deactivation. Application of HPAs in biodiesel synthesis from waste cooking oil was reported by Cao et al. (2008). $\mathrm{H}_{3} \mathrm{PW}_{12} \mathrm{O}_{40} \cdot 6 \mathrm{H}_{2} \mathrm{O}\left(\mathrm{PW}_{12}\right)$ was used as the HPAs catalyst and the waste cooking oil contained high amount of FFA $(15.65 \%)$ and water content $(0.1 \%)$. Optimum yield of $87 \%$ biodiesel was attained at reaction temperature of $65^{\circ} \mathrm{C}$, methanol to oil molar ratio of 70:1 and $14 \mathrm{~h}$ of reaction time. At the same time, $4 \AA$ zeolite was introduced into the reaction media as an adsorbent for water. Although $\mathrm{PW}_{12}$ has a high tolerance towards FFA content and is stable even after 5 reaction cycles, however, relatively high methanol to oil molar ratio and long reaction time may restrict the application of this catalyst in industrial scale. Moreover, the catalyst was found not stable when reaction temperature was increased more than $60^{\circ} \mathrm{C}$. The authors claimed that this 
observation is due to the nature of waste cooking oil that contains many undesirable compounds that might have caused side reactions when carrying out transesterification reaction at higher temperature.

On the other hand, attempt was made to synthesize HPA with higher acidity by introducing Lewis acid into HPA, as to contain both Brønsted and Lewis acid sites. This was done by loading Brønsted acidic HPAs on Lewis acidic supporters, such as $\mathrm{ZrO}_{2}, \mathrm{TiO}_{2}$ or $\mathrm{Ta}_{2} \mathrm{O}_{5}$ (Zhang et al., 2009). Proper coordination of a Lewis acid to a Brønsted acid could enhance its original acidity and therefore forming a bifunctional acid site catalyst. Zhang et al. (2009) studied the potential of this double acidic sites of HPAs in transesterification of waste cooking oil. $\mathrm{Zr}_{0.7} \mathrm{H}_{0.2} \mathrm{PW}_{12} \mathrm{O}_{40}$ (ZrHPW) with nanotube structure was successfully synthesized using natural cellulose fiber as a template. ZrHPW exhibited high acidity capacity with $1350 \mu \mathrm{mol} / \mathrm{g}$ acid sites was detected, much higher than its original HPW $(892 \mu \mathrm{mol} / \mathrm{g})$. These high-density acid sites are comparable to recent studies reported in the literature, such as carbonized glucose $(1550 \mu \mathrm{mol} / \mathrm{g})$ and mesoporous sulfated silica zirconia $(1260 \mu \mathrm{mol} / \mathrm{g})$. Apart from that, high biodiesel yield of $98.9 \%$ was attained at reaction temperature of $65^{\circ} \mathrm{C}$, methanol to oil molar ratio of 20 , catalyst loading of $2.1 \%$ and reaction time of $8 \mathrm{~h}$. Moreover, after 5 reaction cycles, biodiesel yield still remain at $95 \%$.

\section{SULFONIC ION-EXCHANGE RESINS}

Ion-exchange resins are insoluble macroporous polymer that are capable of exchanging specific ions within the polymer itself with other ions in a solution or reaction media. Normally, sulfonic ion-exchange resins are copolymers of divinylbenzene (DVB), styrene and sulfonic acid groups (as the active sites-Brønsted acidity) (Özbay et al., 2008). The polymer structure of the resin is mainly characterized by the composition of the cross-linking component (normally DVB), which determines its surface area and pore size distribution (Pääkkönen and Krause, 2003). However, their catalytic activity is also strongly dependent on their swelling properties as the swelling capacity limits reactant accessibility to the acid sites and thus affects their overall activity (Feng et al., 2010). Common types of acidic ion-exchange resin include Amberlyst-15, Amberlyst-35 and Nafion SAC-13. These catalysts were reported to give good performance in FFA esterification, but, weak in transesterification (Vicente et al., 1998). Application of Amberlyst-15 with acidic functional groups has exhibited excellent catalytic activity in esterification reaction. Kiss et al., (2006) tested the activity of several solid acid catalysts in the esterification of dodecanoic acid with 2-ethylhexanol at $150{ }^{\circ} \mathrm{C}$. Amberlyst-15 was found to require the least reaction time to achieve $90 \%$ conversion compared to sulfated zirconia and Nafion-NR50. Similar positive esterification results were also reported by Chen et al. (1999) by using acidic Amberlyst-15.

However, Amberlyst-15 was found to give low performance in transesterification reaction. At a relatively low reaction temperature $\left(60^{\circ} \mathrm{C}\right)$, the conversion of sunflower oil to FAME was reported to be $0.7 \%$, using the following reaction conditions: atmospheric pressure for $8 \mathrm{~h}$ reaction time and 6:1 methanol to oil molar ratio (Vicente et al., 1998). In another study, Dos Reis et al. (2005) reported the transesterification of Babassu coconut oil using Amberlyst-15. They reported that a rather good triglycerides conversion of $80 \%$ could be achieved only if the methanol to oil ratio used is increased to $100: 1$. The reaction temperature and time are at $60{ }^{\circ} \mathrm{C}$ and $8 \mathrm{~h}$ respectively. This finding was rather expected as the activity of solid acid catalysts in transesterification is usually low at low reaction temperature. Consequently, if Amberlyst-15 is to be used, it is necessary to increase the reaction temperature to $150-200{ }^{\circ} \mathrm{C}$ to obtain sufficiently fast reaction rate. However, most ion-exchange resins such as Amberlyst-15 have low thermal stability and become unstable at temperature above $140{ }^{\circ} \mathrm{C}$ (Lotero et al., 
2005). Thus, this problem certainly limits their application to reactions that require high temperatures. Study regarding the deactivation of polystyrene sulfonic acid resins in esterification of high FFAs oils at a higher reaction temperature was reported and discussed extensively by Tesser et al. (2005).

\section{SULFONIC MODIFIED MESOSTRUCTURE SILICA}

Mesostructure materials such as silica have an exceptional potential to be utilized as heterogeneous acid catalyst in biodiesel production. This mesoporous materials (silica) consist of large mesopores which can significantly minimize the diffusion problem for reactants to access the active sites of the catalyst (Mbaraka and Shanks, 2006). Moreover, the physical and chemical properties of these mesoporous materials can be manipulated by incorporating suitable organic or inorganic functional groups into the mesoporous silica matrix (Mbaraka et al., 2006). For instance, in order to obtain a solid acid catalyst, organosulfonic groups can be incorporated onto the mesoporous silica material (Melero et al., 2009). The organosulfonic acid anchored on mesoporous silica acts as Brønsted acid (active sites) that is suitable to catalyze esterification and transesterification reactions. Mesostructure silica materials functionalized with propylsulfonic acid $\left(\mathrm{SO}_{3} \mathrm{H}\right)$ groups have been reported to have good catalytic activity in esterification of refined and unrefined oil (Melero et al., 2009). To date, application of sulfonated silica in transesterification of waste cooking oil is still limited. Most recent studies report focused on transesterification of refined oil rather than oil with high FFA and waste cooking oil. Mbaraka et al. (2006) reported the utilization of acidic mesoporous silica in esterification of beef tallow. From the study, it was found that propylsulfonic acid-functionalized mesoporous silica $\left(\mathrm{SBA}-15-\mathrm{SO}_{3} \mathrm{H}\right)$ has an excellent catalytic activity in esterification. Nearly $95 \%$ conversion of FFA from beef tallow was attained at relatively short reaction time of 30 min, at reaction temperature of $120{ }^{\circ} \mathrm{C}$ and methanol to FFA ratio of 20.

Unfortunately, the catalytic activity of SBA-15- $\mathrm{SO}_{3} \mathrm{H}$ reduced drastically for the subsequent reaction cycles due to accumulation of organic or carbonaceous matter on the catalyst surface that blocks the acidic sites. However, leaching of the active sites was ruled out as the reason for catalyst deactivation since the authors overcame this problem by incorporating an hydrophobic agent (propyltrimethoxysilane) onto $\mathrm{SBA}-15-\mathrm{SO}_{3} \mathrm{H}$ in order to increase its hydrophobicity. This bi-functionized (acidic and hydrophobic) mesostructure silica would have lower pores polarity, thereby reducing the interaction between polar impurities (contained in the beef tallow) with the sulfonic acid groups. Results showed that high FFA conversion (84\%) was maintained for the second cycle of reaction. However, in-depth research and analysis work using sulfonic modified silica in transesterification reaction (typically from high free fatty acid oil) should be carried out to justify the potential of this solid acid catalyst.

\section{SULFONATED CARBON-BASED CATALYST}

Carbon-based catalyst is classified as a type of sugar catalyst, in which sugar, starch or cellulose is carbonized partially at temperature below $500{ }^{\circ} \mathrm{C}$ (Hara, 2009). The incomplete carbonized carbon is then immersed in concentrated sulphuric acid, $\mathrm{H}_{2} \mathrm{SO}_{4}$ (purity $\mathrm{N} 96 \%$ ) and heated to $150{ }^{\circ} \mathrm{C}$ for $15 \mathrm{~h}$ under the flow of $\mathrm{N}_{2}$ (Lou et al., 2008; Nakajima et al., 2007). The resulting catalyst was claimed to be the first of its kind and is called sulfonated carbon-based catalyst, which comprise of high-density functional group such as sulfonic group $\left(\mathrm{SO}_{3} \mathrm{H}\right)$ and carboxyl group $(\mathrm{COOH})$ (Hara, 2009). The minimum unit in this material is a nanographene sheet (ca. $1 \mathrm{~nm})$ comprised of 10-20 carbon six-membered rings (Hara, 2009). In addition, the sulfonated carbon material has a 
high Hammett acid strength $\left(\mathrm{H}_{0}\right)$ of -8 to -11 , which is almost comparable to concentrated $\mathrm{H}_{2} \mathrm{SO}_{4}\left(\mathrm{Okamura}_{\text {et }}\right.$ al., 2006). Furthermore, leaching of $\mathrm{SO}_{3} \mathrm{H}$ group was not observed in the esterification of high free fatty acid oil (Takagaki et al., 2006). Such finding did not only open up a new route to minimize extensively the usage of $\mathrm{H}_{2} \mathrm{SO}_{4}$ in the industries, but also lead to a greener approach for producing acid-based catalyst. However, it should be noted that the carbon-based catalyst could not be prepared by sulfonation of an incomplete carbonized resin, amorphous glassy carbon, activated carbon or natural graphite (Hara, 2009). Heating these carbon materials with $\mathrm{H}_{2} \mathrm{SO}_{4}$ will only result to low density $\mathrm{SO}_{3} \mathrm{H}$ groups and do not function as a solid acid catalyst. Up to date, there are only minimal studies that reported the use of carbon-based material for biodiesel production.

In a recent study, various sulfonated carbon-based catalysts were derived, mainly from starch, cellulose, sucrose and D-glucose (Lou et al., 2008). It was found that carbon-based catalyst derived from starch has a relatively larger-pore volume $\left(0.81 \mathrm{~cm}^{3} / \mathrm{g}\right)$ and pore size $(8.2 \mathrm{~nm})$ allowing better access to the $\mathrm{SO}_{3} \mathrm{H}$ sites by reactants. Moreover, starch derived carbon-based catalyst also have a relatively higher total acid site (1.97 $\mathrm{mmol} / \mathrm{g}$ ) and higher sulphur content (5.9 wt.\%). In addition, high FAME yield of 92\% was attained from transesterification of waste cooking oil at reaction temperature of $80^{\circ} \mathrm{C}$, methanol to oil molar ratio of 30 , catalyst loading of $10 \mathrm{wt} . \%$ (referred to weight of oil) and reaction time of $8 \mathrm{~h}$. Furthermore, the catalyst was found to be stable even after fifty cycles of repeated reaction. Nevertheless, this catalyst must be further improved through proper optimization during the catalyst preparation as well as transesterification reaction conditions (Man et al., 2010).

\section{ENZYME (BIOCATALYST) CATALYZED TRANSESTERIFICATION}

Enzymatic transesterification especially those using lipase has drawn researcher's attention in the last fifteen years due to the downstream processing problem posed by chemical transesterification (Man et al., 2010). Huge amount of wastewater generation and difficulty in glycerol recovery are among problems that eventually increase the overall biodiesel production cost especially not being environmentally benign. In contrast, enzyme catalysis proceeds without the generation of by-products, with easy recovery of product, mild reaction condition, insensitive to high FFA oil and it can be reused (Kulkarni et al., 2006). Some of the enzymes that have been studied on their capability of effectively carrying out transesterification by various researches include Mucor miehei (Lipozym IM 60), Pseudomonas cepacia (PS 30), C. antarctica (Novozym 435), Bacillus subtilis, Rhizopus oryzae and Penicillium expansum, to mention but a few.

These advantages prove that enzyme catalyzed biodiesel production has a high potential to be an ecofriendly process and a promising alternative to chemical process. However, it still has its fair share of constraints such as high cost of enzyme, slow reaction rate and enzyme deactivation especially when implemented on industrial scale (Bajaj et al., 2010). In a study by Nelson et al. (1996), Lipozym IM 60 was found to show a promising result in transesterification of tallow with high FFA content. Based on the study, two different types of alcohols were investigated: (1) primary alcohols, such as methanol, ethanol, propanol, butanol and isobutanol and (2) secondary alcohol, such as isopropanol and 2-butanol. The effect of adding solvent (hexane) into the reaction mixture was also studied. The purpose of introducing solvent into enzymatic transesterification process is to increase the solubility between methanol and glycerol which minimizes the possibility of enzyme deactivation caused by methanol and glycerol (Halim and Harun, 2008). It was found that Lipozym IM 60 is a promising enzyme in transesterification of tallow with primary alcohol resulting in biodiesel yield as high as 93-99\%. The 
optimum reaction conditions were: reaction temperature at $45{ }^{\circ} \mathrm{C}$, stirring speed of $200 \mathrm{rpm}, 5 \mathrm{~h}$ reaction time, 0.34 molar of triglyceride in hexane, methanol to oil molar ratio of 3 and 12.5-25\% enzyme (by weight of tallow). However, for secondary alcohol, the yield of biodiesel obtained was relatively low. Only 19-24\% of biodiesel yield was obtained using the same reaction condition as primary alcohols. No explanation was given for this observation. On the other hand, in a solvent-free system (without the addition of hexane), biodiesel yield dropped significantly to $20-65 \%$ when methanol or ethanol were used as primary alcohol. Nevertheless, if branched primary alcohol (isopropanol) was used in a solvent-free system, high yield of biodiesel (97\%) could be maintained (Nelson et al., 1996). The main advantage of using secondary alcohol in biodiesel production is to reduce the solidification point and subsequently improve its cloud and pour points characteristic (Salis et al., 2005).

\section{CARBON-BASED HETEROGENEOUS ACID CATALYST PREPARATION}

There are approaches to carbon-based heterogeneous acid catalyst preparation from several sources. Shimin et al., (2011), discussed some of these methods, namely; directly incomplete $\mathrm{H}_{2} \mathrm{SO}_{4}$ carbonization, sulfonation of biomass carbonization products, special structure carbon-based sulfonated (CBSC) preparation, CBSC synthesis by special sulfonating agents, synthesis of resin/PVC derived CBSC, CBSC preparation by thermolysis of polymer and preparation of special ingredient loaded CBSC. Among these methods of preparation of CBSC, directly incomplete $\mathrm{H}_{2} \mathrm{SO}_{4}$ carbonization and sulfonation of biomass have been widely adopted in preparing CBSC for biodiesel synthesis. Some researchers have developed several CBSC for this purpose (Nakajima and Hara, 2012; Chang et al., 2013). Guo et al. (2011) prepared CBSC from a mixture of glucose and starch for biodiesel production. Directly incomplete $\mathrm{H}_{2} \mathrm{SO}_{4}$ carbonization was adopted in which glucose and corn powder were mixed in the ratio of $1: 1$ and carbonized at $400^{\circ} \mathrm{C}$ for $75 \mathrm{~min}$. It was sulfonated with concentrated $\mathrm{H}_{2} \mathrm{SO}_{4}(98 \%)$ at $150^{\circ} \mathrm{C}$ for $5 \mathrm{~h}$. The catalyst developed, gave a conversion of 96 and $69 \%$ for oleic acid esterification and triolein transesterification respectively. In a related research work, Qing et al. (2010) used CBSC developed by sulfonating a carbonized vegetable oil asphalt to synthesize biodiesel from waste vegetable oil. The conversion of triglyceride and FFA reached $80.5 \mathrm{wt} \%$ and $94.8 \mathrm{wt} \%$ after 4.5 at $220^{\circ} \mathrm{C}$ when $16.8 \mathrm{M}$ ratio of methanol to oil and $0.2 \mathrm{wt} \%$ to oil were used. Development of CBSC for biodiesel production at a cheaper cost has attracted great research interest. This is because it is a solid acid catalyst that can catalyze non-edible oils of very high FFA which suggests the that current drawbacks being experienced with other homogeneous catalyst will be resolved. In addition, biomass, especially agro wastes can be developed into CBSC, which will go a long way in reducing the cost of solid catalyst and provide an avenue for exploring the vast non-edible oil resources for biodiesel synthesis.

\section{CONCLUSION}

The roles of various catalysts, from homogeneous and heterogeneous acid and base catalysts to bio-catalysts and resins for biodiesel synthesis have been reviewed. Their various advantages and disadvantages were also discussed. Carbon-based heterogeneous catalyst has been tipped as the heterogeneous solid acid catalyst that has very promising potentials in utilizing oils of very high FFA in simultaneous esterification and transesterification reactions for vegetable oil synthesis. The raw materials for their synthesis are agro-based and readily available, mainly agro-wastes. The carbon-based synthesis process approaches are easy, simple and the resulting catalysts are very stable and have a very higher degree of reusability. In view of the numerous advantages of carbon-based 
catalyst over others, more researches should be geared toward developing those that could operate under mild process condition in very short possible time. Moreover, research interests should also be shifted toward designing and developing various reactors for effective utilization of carbon-based catalyst for biodiesel production from non-edible and waste cooking oils on industrial scale.

\section{REFERENCES}

Adepoju, T. F. and Olawale, O. (2014). Acid-Catalyzed Esterification of Waste Cooking Oil with High FFA for Biodiesel Production. Chemical and Process Engineering Research, 21:80-85

Akande, S.O and Olorunfemi, F.B (2009). Research and Development Potentials in Biofuel Production in Nigeria. African Research Review, 3(3): 34-45

Alamu, O.J, Waheed, M.A., and Jekayinfa, S.O. (2007). Biodiesel Production from Nigerian Palm Kernel Oil: Effect of KOH Concentration on Yield. Energy for Sustainable Development, 11(3): 77-82

Anwar, F., Rashid, U., Ashraf, M. and Nadeem, M. (2010). Okra (Hibiscus esculentus) seed oil for biodiesel production. Applied Energy, 87:779-85.

Aransiola, E.F., Daramola, M.O. and Ojumu, T.V., Aremu, M.O. and Layokun, S.K. Bamidele Ogbe Solomon. (2012). Nigerian Jatropha Curcas Oil Seeds: Prospect for Biodiesel Production in Nigeria. International Journal of Renewable Energy Research, 2(2): 317-325

Aransiola, E. F., Ojumu, T.V., Oyekola, O.O., Madzimbamuto, T.F. and Ikhuomoregbe, D.I.O. (2014). A review of current technology for biodiesel production: State of the art. Biomass and Bioenergy, 61: 276-297, doi: 10.1016/j.biombioe.2013.11.014

Axens Technologies (2010). Processes, Catalysts, Adsorbents and Advanced Services. Retrieved on $12^{\text {th }}$ January, 2020 from http://www.axens.net/html-gb/offer/offer_market_10.html.php

Babajide, O., Petrik, L. and Ameer, F. (2015). Technologies for Biodiesel Production in Sub-Saharan African Countries. Retrieved on $15^{\text {th }}$ February, 2020 from https://cdn.intechopen.com/pdfs-wm/48141.pdf

Balaji, B.S. and Chanda, B.M. (1998). Simple and high yielding syntheses of $\beta$-keto esters catalysed by zeolites. Tetrahedron, 54:13237-52.

Brito, A., Borges, M.E. and Otero, N. (2007). Zeolite Y as a heterogeneous catalyst in biodiesel fuel production from used vegetable oil. Energy Fuels, 21:3280-3.

Canakci, M. and Sanli, H. (2008). Biodiesel production from various feedstocks and their effects on the fuel properties. Journal of Industrial Microbiology and Biotechnology, 35:431-41.

Canakci, M. and Van Gerpen, J. (2003). A pilot plant to produce biodiesel from high free fatty acid feedstocks. Transactions of the American Society of Agricultural Engineers (ASAE), 46:945-954.

Chen, Y., Xiao, B., Chang, J., Fu, Y., Lv. P. and Wang, X. (2009). Synthesis of biodiesel from waste cooking oil using immobilized lipase in fixed bed reactor. Energy Conversion Management, 50:668-73.

Chin, L.H., Hameed, B.H. and Ahmad A.L. (2009). Process optimization for biodiesel production from waste cooking palm oil (Elaeis guineensis) using response surface methodology. Energy Fuels, 23:1040-4

Chung, K.H., Chang, D.R. and Park, B.G. (2008). Removal of free fatty acid in waste frying oil by esterification with methanol on zeolite catalysts. Bioresource Technology, 99:7438-43.

MacLeod, C.S., Harvey, A.P., Lee, A.F., Wilson K. (2008). Evaluation of the Activity and Stability of Alkalidoped Metal Oxide Catalysts for Application to an Intensified Method of Biodiesel Production. Chemical Engineering Journal, 135: 63-70. 
Corma, A. and Garcia, H. (1997). Organic reactions catalyzed over solid acids. Catalysis Today, 38:257-308.

De Almeida, R.M., Noda, L.K., Gonçalves, N.S., Meneghetti, S.M.P. and Meneghetti, M.R. (2008).

Transesterification reaction of vegetable oils, using superacid sulfated $\mathrm{TiO}_{2}$-base catalysts. Applied Catalysis A, 347:100-105.

Demirbas, A. (2005). Biodiesel production from vegetable oils via catalytic and non-catalytic supercritical methanol transesterification methods. Progress in Energy and Combustion Science, 31: 466-87.

Di Serio, M., Tesser, R., Pengmei, L. and Santacesaria, E. (2008). Heterogeneous catalysts for biodiesel production. Energy Fuels, 22:207-17.

Dizge, N. and Keskinler, B. (2008). Enzymatic production of biodiesel from canola oil using immobilized lipase. Biomass Bioenergy, 32:1274-8.

Dos Reis, S.C.M., Lachter, E.R., Nascimento, R.S.V, Rodrigues Jr, J.A. and Reid, M, G. (2005). Transesterification of Brazilian vegetable oils with methanol over ion-exchange resins. Journal of the American Oil Chemists' Society, 82:661-5.

Elegbede, I. and Guerrero, C. (2016). Algae Biofuel in the Nigerian Energy Context. Environmental and Climate Technologies 2016(17): 44-60

Endalew, A. K., Kiros, Y. and Zanzi, R. (2011). Inorganic heterogeneous catalysts for biodiesel production from vegetable oils. Biomass and bioenergy, 35: 3787-3809.

Felizardo, P., Neiva Correia, M.J., Raposo, I., Mendes, J.F., Berkemeier, R. and Bordado, J.M. (2006). Production of biodiesel from waste frying oils. Waste Management, 26:487-94.

Feng, Y., He, B., Cao, Y., Li, J., Liu, M. and Yan, F. (2010). Biodiesel production using cation-exchange resin as heterogeneous catalyst. Bioresource Technology, 101:1518-21.

Fukuda, .H, Kondo, A. and Noda, H. (2001) Biodiesel fuel production by transesterification of oils. Journal Bioscience and Bioengineering, 92:405-16.

Granados, M.L., Poves, M.D.Z., Alonso, D.M., Mariscal, R., Galisteo, F.C. and Moreno-Tost, R. (2007). Biodiesel from sunflower oil by using activated calcium oxide. Applied Catalysis B, 73:317-26.

Guan, G., Kusakabe, K., Sakurai, N. and Moriyama, K. (2009). Transesterification of vegetable oil to biodiesel fuel using acid catalysts in the presence of dimethyl ether. Fuel, 88:81-6.

Haas, M.J., McAloon, A.J., Yee, W.C. and Foglia, T.A. (2006). A process model to estimate biodiesel production costs. Bioresource Technology, 97:671-8.

Halim, S.F.A. and Harun, K. A. (2008). Catalytic studies of lipase on FAME production from waste cooking palm oil in a tert-butanol system. Process Biochemistry, 43:1436-9.

Hara, M. (2009). Environmentally benign production of biodiesel using heterogeneous catalysts. ChemSusChem, 2:129-35.

Helwani, Z., Othman, M.R., Aziz, N., kim, J. and Fernando, W.J.N. (2009). Solid catalysis for transesterification of triglycerides with methanol. Applied Catalysis A, 363:1-10.

Ishola, M.M., Brandberg. T., Sanni, S.A. and Taherzadeh, M. J. (2013). Biofuels in Nigeria: A critical and strategic evaluation. Renewable Energy, 55: 554-560

Jacobson, K., Gopinath, R., Meher, L.C. and Dalai, A.K. (2008). Solid acid catalyzed biodiesel production from waste cooking oil. Applied Catalysis B: Environmental, 85:86-91.

Jitputti, J., Kitiyanan, B., Rangsunvigit, P., Bunyakiat, K., Attanatho, L. and Jenvanitpanjakul, P. (2006). 
Transesterification of crude palm kernel oil and crude coconut oil by different solid catalysts. Chemical Engineering Journal, 116: 61-66.

Kiss, A.A., Dimian, A.C., Rothenberg, G. (2006). Solid acid catalysts for biodiesel production — towards sustainable energy. Advanced Synthesis and Catalysis, 348:75-81.

Kouzu, M., Kasuno, T., Tajika, M., Yamanaka, S. and Hidaka, J. (2008). Active phase of calcium oxide used as solid base catalyst for transesterification of soybean oil with refluxing methanol. Applied Catalysis A: General., 334:357-365.

Kulkarni, M.G., Gopinath, R., Meher, L.C. and Dalai, A.K. (2006). Solid acid catalyzed biodiesel production by simultaneous esterification and transesterification. Green Chemistry, 8: 1056-62.

Lee, D.W, Park, Y.M. and Lee, K.Y. (2009). Heterogeneous base catalysts for transesterification in biodiesel synthesis. Catalysis Survey from Asia, 13:63-77.

Lotero, E., Liu, Y., Lopez, D.E., Suwannakarn, K., Bruce, D.A. and Goodwin, J.G. (2005). Synthesis of biodiesel via acid catalysis. Industrial Engineering and Chemistry Research, 44: 5353-5363.

Lou, W.Y., Zong, M.H. and Duan, Z.Q. (2008). Efficient production of biodiesel from high free fatt y acidcontaining waste oils using various carbohydrate-derived solid acid catalysts. Bioresource Technology, 99:8752-8.

Macedo, C.C.S., Abreu, F.R., Tavares, A.P., Alves, M.P., Zara, L.F. and Rubim, J.C. (2006). New heterogeneous metal-oxides-based catalyst for vegetable oil transesterification. Journal of Brazilian Chemical Society, 17:1291-6.

Marchetti, J.M., Miguel, V.U. and Errazu, A.F. (2007). Possible methods for biodiesel production. Renewable and Sustainable Energy Reviews, 11:1300-11.

Mbaraka, I.K., McGuire, K.J. and Shanks, B.H. (2006). Acidic mesoporous silica for the catalytic conversion of fatty acids in beef tallow. Industrial Engineering and Chemistry Research, 45:3022-8.

Melero, J.A., Iglesias, J. and Morales, G. (2009). Heterogeneous acid catalysts for biodiesel production: current status and future challenges. Green Chemistry, 11:1285-308.

Miao, C.X. and Gao, Z. (1997). Preparation and properties of ultrafine SO4 2-/ZrO2 superacid catalysts. Materials Chemistry and Physics, 50:15-9.

Muniyappa, P.R., Brammer, S.C. and Noureddini, H.,(1996). Improved conversion of plant oils and animal fats into biodiesel and co-product. Bioresource Technology, 56:19-24.

Nag, A. (2008). Biofuels refining and performance, 165-187. New York, NY: McGraw Hill Education.

Nakajima, K., Hara, M. and Hayashi, S. (2007). Environmentally benign production of chemicals and energy using a carbon-based strong solid acid. Journal of the American Ceramic Society, 90:3725-34.

Narasimharao, K., Brown, D.R., Lee, A.F., Newman, A.D., Siril, P.F. and Tavener, S.J. (2007). Structure-activity relations in Cs-doped heteropolyacid catalysts for biodiesel production. Journal of Catalysis, 248:22634.

Ogbonna I. O., Moheimani N. R. and Ogbonna J. C. (2015). Potentials of Microalgae Biodiesel Production in Nigeria. Nigerian Journal of Biotechnology 29: 44 - 55

Okamura, M., Takagaki, A., Toda, M., Kondo, J.N., Domen, K. and Tatsumi, T. (2006). Acid-catalyzed reactions on flexible polycyclic aromatic carbon in amorphous carbon. Chemistry of Materials, 18:3039-45.

Oku, T., Nonoguchi, M., Moriguchi, T., Oku, T., Nonoguchi, M. and Moriguchi, T. (2006). Method of producing 
of fatty alkyl esters and/or glycerine and fatty acid alkyl ester-containing composition. World Organization Patent 2006088254

Okuhara T. (2002). Water-tolerant solid acid catalysts. Chemical Reviews, 102:3641-66.

Oniya, O.O., Bamgboye, A.I. (2014). Performance of a stationary diesel engine using loofah (Luffa cylindrica, L.) biodiesel. International Journal of Sustainable Energy, 35(6): 1-10

Özbay, N., Oktar, N. and Tapan, N.A. (2008). Esterification of free fatty acids in waste cooking oils (WCO): role of ion-exchange resins. Fuel, 87:1789-98.

Pääkkönen, P.K. and Krause, A.O.I. (2003). Diffusion and chemical reaction in isoamylene etherification within a cation-exchange resin. Applied Catalysis A, 245:289-301.

Park, Y.M., Lee, D.W., Kim, D.K., Lee, J.S. and Lee, K.Y. (2008). The heterogeneous catalyst system for thecontinuous conversion of free fatty acids in used vegetable oils for the production of biodiesel. Catalysis Today, 131:238-43.

Peng, B.X., Shu, Q., Wang, J.F., Wang, G.R., Wang, D.Z. and Han, M.H. (2008) Biodiesel production from waste oil feedstocks by solid acid catalysis. Process Safety and Environmental Protection, 86:441-7.

Pinzi, S., Garcia, I.L., Lopez-Gimenez, F.J., Luque de Castro, M.D., Dorado, G. and Dorado, M.P. (2009). The ideal vegetable oil-based biodiesel composition: a review of social, economic and technical implications. Energy Fuels, 23:2325-41.

Sakai, T., Kawashima, A.and Koshikawa, T. (2009). Economic assessment of batch biodiesel production process using homogeneous and heterogeneous alkali catalysts. Bioresource Technology, 100: 3268-3276.

Salis, A., Pinna, M., Monduzzi, M. and Solinas, V. (2005). Biodiesel production from triolein and short chain alcohols through biocatalysis. Journal of Biotechnology, 119: 291-9.

Sivasamy, A., Cheah, K.Y., Fornasiero, P., Kemausuor, F., Zinoviev, S. and Miertus, S. (2009). Catalytic applications in the production of biodiesel from vegetable oils. ChemSusChem, 2: 278-300.

Stavarache, C., Vinatoru, M., Nishimura, R. and Maed, Y. (2005). Fatty acids methyl esters from vegetable oil by means of ultrasonic energy. Ultrasonics Sonochemistry, 12: 367-72.

Suarez, P.A.Z., Plentz Meneghetti, S.M., Meneghetti, M.R. and Wolf, C,R. (2007). Transformation of triglycerides into fuels, polymers and chemicals: some applications of catalysis in oleochemistry. Quimica Nova, 30: 667-76.

Takagaki, A., Toda, M., Okamura, M., Kondo, J.N., Hayashi, S. and Domen, K. (2006). Esterification of higher fatty acids by a novel strong solid acid. Catalysis Today, 116: 157-61.

Tanabe, K. and HoE` lderich, W.F. (1999). Industrial application of solid acid-base catalysts. Applied Catalysis A, 181: 399-434.

Tesser, R., Di Serio, M., Guida, M., Nastasi, M. and Santacesaria, E. (2005). Kinetics of oleic acid esterification with methanol in the presence of triglycerides. Industrial Engineering and Chemistry Research, 44:7978-82.

Vicente, G., Coteron, A., Martinez, M. and Aracil, J. (1998). Application of the factorial design of experiments and response surface methodology to optimize biodiesel production. Industrial Crops and Products, 8:29-35.

Wang, Y., Ou, S., Liu, P., Xue, F. and Tang, S. (2006). Comparison of two different processes to synthesize biodiesel by waste cooking oil. Journal of Molecular Catalysis A: Chemical, 252: 107-112.

West, A.H., Posarac, D. and Ellis, N., (2008). Assessment of four biodiesel production process using HYSYS 
plant. Bioresource Technology, 99: 6587-6601.

Xavier, N.M., Lucas, S.D. and Rauter, A.P. (2009). Zeolites as efficient catalysts for key transformations in carbohydrate chemistry. Journal of Molecular Catalysis A: Chemical, 305:84-9.

Yadav, G.D. and Murkute, A.D. (2004). Preparation of a novel catalyst UDCaT-5: enhancement in activity of acid-treated zirconia - effect of treatment with chlorosulfonic acid vis-à-vis sulfuric acid. Journal of Catalysis, 224: 218-23.

Zabeti, M., Daud, W.M.A.W. and Aroua, M.K., (2009). Activity of solid catalysts for biodiesel production: a review. Fuel Processing Technology, 90:770-777.

Zhang, Y., Dub, M.A., McLean, D.D. and Kates, M. (2003). Biodiesel production from waste cooking oil: 2. Economic assessment and sensitivity analysis. Bioresource Technology, 90:229-40. 